\title{
The role of teacher identity in teacher self-efficacy development: the case of Katie
}

\author{
Gosia Marschall ${ }^{1,2}$ (D)
}

Accepted: 17 August 2021 / Published online: 30 August 2021

(C) The Author(s) 2021

\begin{abstract}
This article illustrates the role of teacher identity in teacher self-efficacy development during initial teacher education. It has been posited that teacher self-efficacy develops on the basis of information accessed through four self-efficacy sources: vicarious and enactive experiences, social persuasion, and physiological and affective states, and by interacting with a myriad of personal and external factors. The very process of teacher self-efficacy development, however, is not well understood. This phenomenological longitudinal qualitative case study contributes to addressing this issue by illustrating how a pre-service secondary mathematics teacher's teacher self-efficacy is affected by the way she sees herself. More specifically, the study illustrates how aspects of a strong student teacher identity negatively affect the pre-service teacher's teacher self-efficacy appraisal, and how her teacher identity, emerging through the processes of autonomous role enactment and social verification, supports teacher self-efficacy development.
\end{abstract}

Keywords Abductive phenomenological approach · Secondary mathematics teacher education · Teacher identity $\cdot$ Teacher self-efficacy $\cdot$ Longitudinal qualitative study

\section{Introduction}

Teacher self-efficacy (TSE), defined as teachers' judgement of their capability to effectively organise and execute specific courses of action (Bandura, 2006), has long been contended one of the most significant factors in teacher functioning (Soini, et al., 2015). Research to date has shown correlations between strong TSE and teachers' greater willingness to engage with innovative teaching approaches (e.g. Nie, et al., 2013; Thurlings et al., 2015), higher quality of classroom instruction (Holzberger et al., 2013; Newton, et al., 2012) and more effective behaviour management (Chacón, 2005). In contrast, teachers with weaker TSE have shown to be more prone to experiencing anxiety (Gresham, 2008) or burnout (Aloe, et al., 2014; Collie et al., 2012; Klassen \& Chiu, 2010; Zee \& Koomen, 2016). This made TSE highly attractive in the context of educational research.

Gosia Marschall

gosia.marschall@mnd.su.se; mzm21@cam.ac.uk

1 Department of Mathematics and Science Education, Stockholm University, Stockholm, Sweden

2 Faculty of Education, University of Cambridge, Cambridge, UK 
From a theoretical perspective, Bandura (1997) defines self-efficacy as a dynamic selfschema related to one's view of oneself acting competently in the world. As a cognitive and affective mental construct, such self-schema refers to a set of memories which include one's beliefs and experiences related to specific behavioural domains, perceptions and generalisations of self, which interweave one's past, present and future selves in the process of appraisal (Marschall \& Watson, forthcoming). Conceptualised this way, TSE should not be viewed as a simple belief (Marschall \& Watson, forthcoming) or a general trait of one's character (such as for example being a confident person) but rather as a dynamic view that one holds about oneself as a teacher acting competently in the world (Bandura, 1997). Such a conceptualisation, however, leads to a question about how TSE relates to teacher identity, which has also been recognised to have an important relationship with professional experience, action (Watson, 2006) and learning (Sfard, 2019; Sfard \& Prusak, 2005), has also been related to one's evolving view of oneself in the professional context (Sfard, 2019), and has also been connected to wider issues such as, for example, teacher attrition (CochranSmith et al., 2014). In grappling with this question, I turn to the theory of self.

In socio-psychological terms the development of self as a competent teacher is seen as a dynamic system which encapsulates one's personality, identity, responsibilities and professional capacity (Smith, 2014). Such a view considers both teacher identity and TSE as part of one dynamic concept of self (Canrinus, et al., 2012; Kelchtermans, 2009). Despite this theoretical connection, however, and although studies in both teacher identity and TSE are prominent in the field of education, qualitative research investigating their interaction in the development of self is still sparse. Although there is a growing acceptance that the two processes (teacher identity formation and TSE development) are in a symbiotic relationship, most of the up-to-date research focuses predominantly on one aspect of this relationship. Such research emphasises the importance of TSE in the process of teacher identity formation (Day \& Gu, 2007), indicating that one establishes one's identity partially through a self-assessment of their competence in the specific role enactment. It categorises TSE as an important aspect of teacher identity (Garner \& Kaplan, 2019; Hong, 2010; van der Want et al., 2019), an indicator of teacher identity (Kelchtermans, 2009) or a significant factor contributing to teacher identity formation (Canrinus et al., 2012). Yet, the process of TSE development itself is not a simple "mechanical audit" (Bandura, 1997, p. 81) of one's past performances, devoid of one's view of oneself in the world. It is rather a cognitive construction of knowledge and understanding of one's competence highly dependent on who one sees oneself to be and what role one occupies in society. As we know, "teachers use identity to make sense of themselves as teachers" (Beijaard et al., 2004, pp. 123) and this can include making sense of their competence. This suggests that teacher identity might also represent a key variable in development of TSE. However, with an exception of handful of studies attending to this issue (e.g. through the means of variance model analysis Moslemi and Habibi (2019) have shown that a growing professional identity of English language teachers in Iran had a positive effect on their developing TSE), this is an aspect of theory which remains underreported in empirical studies.

In my research with pre-service secondary mathematics teachers I investigated the process of TSE development. This work was driven by the field's limited understanding of such a process (Philippou \& Pantziara, 2015). This, as I argue elsewhere, has been the result of a tendency to reduce the complexity of concept of TSE to something that can be easily captured or measured (Marschall \& Watson, forthcoming). Yet, what was evident in my research aligned with Bandura's conceptualisation of TSE as a complex construct, inextricably connected to the pre-service teachers' evolving sense of themselves as teachers (or, as I suggest, their professional identity). This article focuses explicitly on reporting 
evidence supporting this assertion. More specifically, the study illustrates how one preservice secondary mathematics teacher's TSE appraisal was affected by her evolving professional identity. As such, the findings contribute to extending our understanding of TSE development and illuminate an aspect of the relationship between teacher identity and TSE.

It is important to emphasise at this stage that this article does not engage with providing a full account of the pre-service teacher's identity formation or a bidirectional relationship between identity and TSE. What I present here can be thought of as a stepping stone towards developing this argument, the predominant goal of which is to highlight the important role that professional identity plays in TSE appraisal. This illustration seems to be particularly important in the field which continues to limit descriptions of TSE development in terms of basic posits of self-efficacy theory, revolving mainly around four self-efficacy sources and a role of limited number of personal and contextual factors, such as subject knowledge or environmental circumstances, in this process (Glackin \& Hohenstein, 2018).

\section{Teacher self-efficacy development}

It has long been established that TSE develops through cognitive processing of information accessed through four self-efficacy sources (Bandura, 1997). Mastery experiences (ME) provide a teacher with information about the success of their performance through enactment. Vicarious experiences (VE) involve observations of others and an assessment of one's capabilities based on the observed success of others and the similarities between oneself and those others. Social and verbal persuasion (VP) includes social feedback and support, which represent both a realistic assessment of one's capabilities as well as words of encouragement. Physiological and affective states (PAS) include affective and physical reactions related to one's performance (either as a result of such performance or in its anticipation) (Bandura, 1997).

In the process of TSE appraisal the information accessed through the four self-efficacy sources undergoes processing which attends to an assessment of one's behavioural success and its attribution, effort expenditure, and a consideration and weighing of the role of both personal and environmental factors in achieving this success (Bandura, 1997). Such factors can include personal characteristics (Poulou, 2007), culture (e.g. Cheung, 2008; Klassen et al., 2009), school's structure and students' economic status (e.g. Adams \& Forsyth, 2006), social interaction and relationships (e.g. Skaalvik \& Skaalvik, 2007) or environmental circumstances (Bandura, 1997). In mathematics teacher education among the most frequently discussed factors are teacher subject knowledge (e.g. Bates et al., 2011; Gresham, 2007; Morris et al., 2017; Sinclair et al., 2011; Thompson et al., 2017; Tschannen-Moran \& Johnson, 2011) and teachers' individual interest in and passion for mathematics (Alrajhi et al., 2017; Craft et al., 2014; Ekstam et al., 2017; Long \& Woolfol Hoy, 2006).

\section{Teacher identity}

Research in mathematics teacher identity is ubiquitous (Graven \& Heyd-Metzuyanim, 2019), with the field being saturated with a multiplicity of definitions of teacher identity (Lutovac \& Kaasila, 2018) stemming from a variety of different perspectives (Darragh, 2016; Graven \& Heyd-Metzuyanim, 2019). These perspectives can be broadly categorised into: participative, narrative, discursive, psychoanalytic or performative (Darragh, 2016). Being phenomenological, this study focuses on the individual and their sense-making of their experiences and capabilities during initial teacher education; an 
individual perspective which, as Lutovac and Kaasila (2018) advocated, links to the core of the concept of identity. Consequently, the conceptualisation of identity in this study aligns with a socio-psychological perspective which describes identity as a dynamic narrative (or storytelling) that one constructs about oneself in the light of who one sees oneself to be and who one aspires to become (Archer, 2000; Bruner, 1990; Sfard \& Prusak, 2005). In this sense we consider two aspects of narrative identity: "actual identity, consisting of stories about the actual state of affairs, and designated identity, composed of narratives presenting a state of affairs which ... is expected to be the case" (Sfard \& Prusak, 2005, p. 16).

Constructing one's narrative identity (i.e. narrativising about oneself) takes place through the process of sense-making and interpretation of one's own characteristics, values, beliefs and experiences (Flores \& Day, 2006), social interactions (Garner \& Kaplan, 2019) and expectations of a particular context (Katz, et al., 2011), and a necessary internalisation of those understandings (Brenner et al., 2014; Monrouxe et al., 2011). As such it consists of multiple dimensions (such as personal or social) which get unified in one narrative discourse (Hamman et al., 2010). Narrative construction evolves as part of communicational practice in which individuals story about their lives in communication with and by engaging with others (Sfard \& Prusak, 2005). In this sense, narrative identity is considered to be both internal and external. It can be understood as a way in which individual teachers view themselves and others, and how they believe they are perceived by those others (Czerniawski, 2011) with reference to social circumstances defined by everyday social interactions, roles or structures (Côté \& Levine, 2014).

Identity narrativising revolves around significant experiences (Archer, 2000; Bruner, 1990) or critical stories (Sfard \& Prusak, 2005). Among those the most significant ones tend to be "those that imply one's memberships in, or exclusions from, various communities" (Sfard \& Prusak, 2005, p. 11). When critical stories align with one's view of oneself or, as Bruner (1990) says "when things are as they should be" (p.40), the narrativising tends to remain seamless. When they expose discrepancies or gaps between their actual and designated identities, however, they can lead individuals to questioning their identity (Sfard \& Prusak, 2005), which initiates a conscious process of sense-making within the narrative process (Archer, 2000; Bruner, 1990). If persistent, the discrepancies are likely to generate negative affective response (such as feeling of stress or unhappiness) (Archer, 2000; Bruner, 1990; Sfard \& Prusak, 2005).

In the discursive narrative identity research identifying identity-related expressions can relate to so-called "is-sentences" (Sfard \& Prusak, 2005, p. 10) which describe the kind of person one says one is. Such is-sentences can be constructed around the following processes. Self-identification relates to categorising oneself as an occupant of a specific role and is based on a cognitive appraisal (cognitive categorisation of the membership or a role (Carter, 2013)) or a reflected appraisal (general perceptions and interpretations of others' appraisals of oneself (Davis, et al., 2019)). Role enactment involves an active realisation of particular role expectations (Brenner et al., 2014; Stryker \& Burke, 2000). Social verification relates to a mutual validation of identities of different actors involved in one professional context (Burke \& Stets, 1999). It can take place through interpersonal processes (Carter, 2013) such as feedback or non-verbal interactions, or it can be depicted in how individuals feel about themselves and others (James-Wilson, 2001). For example, in the context of initial teacher education, developing student-teacher relationships is often used as an indicator of pre-service teachers' emergence of their professional identity (Pillen et al., 2013). 


\section{Methodology}

The design of the study was founded on the premise that investigating the development of TSE as a dynamic schema that one constructs about oneself necessitates engagement with rich qualitative and sustained interpretative research (Holzberger et al., 2013) which gives access to reflective practices of its participants (Labone, 2004). With this in mind, the current study was phenomenological, seeking "to describe the essence of a phenomenon [here TSE development] by exploring it from the perspective of those who have experienced it" (Neubauer et al., 2019, p. 91).

It is a longitudinal single case study (Yin, 2018) of a pre-service secondary mathematics teacher, Katie (pseudonym). The case study approach was chosen because of its power in providing opportunities for challenging our assumptions and preconceptions about the issue in question (Platt, 1988). Smith et al. (2009) emphasise that, in order to avoid fragmentation and misinterpretation of human life and functioning, the development of all knowledge should necessarily engage in an iterative hermeneutic cycle between the particular and the general, where the general has to always comply with the particular. As such, case studies not only can but should hold an important place in theory-related research (Smith et al., 2009). Such position was taken in this study, which recognised that a more in-depth engagement with the phenomenon in question from the perspective of the particular was necessary. Engaging with rich particulars of one case allows us to illuminate the existence of interesting phenomena (Yin, 2018) which, when illustrated in an insightful manner, can often lead to revision of existing theories (Platt, 1988). This focus on illuminating new particulars was at heart of this study.

Focusing on a single case of Katie over a long period of time allowed me not only to be a witness to her developing view of herself as a competent and confident teacher but also to delve deep into the way this development took place over time. Access to rich qualitative data and frequent discussions provided numerous opportunities for investigating an abundance of factors playing a role in her TSE development and possible interactions between them.

\section{Initial Teacher Education (ITE) programme}

The study was undertaken during a one-year, university-led, partnership ITE programme in England, a successful completion of which leads to the award of a Postgraduate Certificate in Education and a Qualified Teacher Status. Teaching on the programme is undertaken by university-based lecturers and school-based teacher mentors. The substantial part of the programme is school-based (over $80 \%$ of the course), spent over two different school placements. During the first part of the programme, from September to December, the pre-service teachers' time is divided between the university and the first school placement (in the ratio of 3:2 days per week, respectively). In January, the university-based sessions pause and, from then on, the pre-service teachers spend all of their time engaging with practice in their second school placement.

During their time in school the pre-service teachers engage in a wide range of activities which relate to all aspects of teachers' professional lives: they engage with a role of a form tutor, fully responsible for an allocated group of students; participate in all school and departmental meetings; communicate with parents; observe classroom practice, plan and teach lessons; and assess students' work. The teaching load of the pre-service teachers' 
increases gradually over the year, leading towards teaching of at least $60 \%$ of a qualified teacher's full contractual timetable by the end of the course.

The reflective element of the course involves receiving, reflecting on and responding to experienced teachers' feedback on taught lessons, weekly discussions with the school mentor, writing weekly reflections and a regular communication with the university mentor, who co-monitors the pre-service teachers' overall progress.

\section{Participant}

Katie was a pre-service secondary mathematics teacher who enrolled on the ITE programme in Sept 2018. She was among four volunteers participating in the study. While all four participants' data resembled similarities in the way in which they indicated the role that identity appeared to play in TSE development, Katie's accounts were the most extensive and, therefore, the most illustrative of this relationship. In this sense, Katie's case can be thought of as an "intensity sample" (Cohen et al., 2011, p. 156), where the data associated with the case allowed for a more in-depth exploration of the phenomenon in question.

Katie has a strong subject knowledge and high aptitude for any mathematics-related activities. These were judged on the basis of Katie's own proclamations, her subject audit (completed during the ITE programme) and her overall education (verified in the process of the university application). Katie enjoys explaining and discussing difficult mathematical concepts, especially with pupils studying higher-level mathematics, where her passion and strong subject-matter knowledge are evident. These attributes were considered important, particularly in the context of TSE and mathematics teacher education, which has a tendency to consider teacher knowledge as sufficient for effective teaching. What Katie's case emphasises, however, is the necessity to look beyond those.

\section{Ethical considerations}

Katie's participation in the study was voluntary. All rights of confidentiality and withdrawal from the study were confirmed in a written consent with Katie.

Although I was a tutor on the programme, I did not take part in the assessment process leading to the award of Katie's teaching qualifications. This helped minimise any of Katie's potential worries about sharing details about her journey, especially those which might have been perceived negatively (such as doubts, uncertainties or lack of confidence in teaching capabilities).

\section{Data collection}

This design of the study was based on suggestions made by Morris et al. (2017), who advocated that qualitative studies in TSE could make use of regularly collected data (which would include observing teachers' acting in the classroom, which could be used to structure rich follow-up discussions with teachers). Consequently, this study draws on multiple sources of empirical data:

- Written weekly target planning documents (a standard requirement of the programme), in which Katie planned her ongoing activities; 
- Written weekly reflections (a standard requirement of the programme), in which Katie reflected on any significant aspects of her journey (the specific content, amount of detail and length of the reflections were not prescribed);

- Lesson observations, which gave opportunities to observe Katie acting in the classroom;

- Interviews, which included questions about all TSE-related aspects arising in all of the above data sources and general questions about Katie's journey, her developing confidence in her actions and its contributing factors.

Data collection was divided into six blocks. The initial block, representing the first two weeks of the academic year, consisted of one short interview and two weekly reflections. Data collection in the remaining five blocks included: Katie's weekly written reflections and lesson planning documents, and fields notes from a lesson observation conducted at the end of the block. Data from all of the above sources were then used to devise a semi-structured interview, which was conducted at the end of the block. The process was repeated 5 times throughout the year.

\section{Data analysis}

The study employed Interpretative Phenomenological Analysis (IPA, Smith, et al., 2009), at the core of which stood the attention to an interpretation and sense-making of "how particular experiential phenomena have been understood from the perspective of particular people" (Smith et al., 2009, p. 29). Since TSE construction represents an ongoing and complex developmental process of oneself, focusing on a single case of Katie and her own specific interpretations of this development felt most appropriate.

The process of analysis of the study was abductive, engaging in an ongoing dialogue between empirical data and theory (Tavory \& Timmermans, 2014). In such an approach, starting from a particular theoretical premise (here self-efficacy theory), the researcher remains vigilant to paying attention to surprising or difficult to explain aspects of the phenomena in question (Tavory \& Timmermans, 2014), which necessitate a turn towards alternative theories, that might help explain or further analyse the arisen query (Tavory \& Timmermans, 2014). This abductive approach allowed me to see the aspects contributing to Katie's TSE development which the self-efficacy theory had not explicitly accounted for (i.e. teacher identity).

The analysis of the study attended to all data collected in the process (described in the previous section) and it involved several iterations. Each stage involved data coding and, to avoid fragmentation, focused on tracing relationships and interactions between those data (Tavory \& Timmermans, 2014). Starting from a specific stand-point of self-efficacy theory, the preliminary coding included recognition of phrases and descriptions related to confidence, affective responses and professional learning. The second round of coding involved sources of TSE and factors interacting with its development (examples of which are presented in Table 1). During this iteration, it became necessary to re-evaluate the selfefficacy theory's lens, which proved insufficient for explaining one particular aspect related to Katie's TSE development — what was becoming evident was that Katie's TSE appraisal was affected by the way she identified herself as a student teacher or a teacher. This led to a necessity to expand the theoretical scope of the study by theory of teacher identity, which initiated two processes. First, it required a review of social psychological theory of teacher identity, necessary for developing an analytical framework for the particular aspect of the 
Table 1 Examples of coding of the data related to TSE, self-efficacy sources and factors

\begin{tabular}{|c|c|}
\hline Code example & Expression \\
\hline \multicolumn{2}{|l|}{ Teacher self-efficacy } \\
\hline $\begin{array}{l}\text { Teacher self-efficacy(related to classroom manage- } \\
\text { ment) }\end{array}$ & $\begin{array}{l}\text { I do not know how I will be able to manage the } \\
\text { students }\end{array}$ \\
\hline Teacher self-efficacy(related to instruction) & I can teach well and explain things well \\
\hline \multicolumn{2}{|l|}{ Sources } \\
\hline Vicarious experiences (VE) & $\begin{array}{l}\text { It's interesting, kind of, seeing classes misbehave } \\
\text { with experienced teachers... }\end{array}$ \\
\hline Mastery experiences (ME) & $\begin{array}{l}\text { When it came to doing it though, as soon as I had } \\
\text { started addressing the class there wasn't any space } \\
\text { left in my head to be nervous! The class were well } \\
\text { behaved, and definitely engaged with the task }\end{array}$ \\
\hline Social verbal persuasion (VP) & $\begin{array}{l}\text { I felt pretty good after my first full lesson on Wednes- } \\
\text { day, the students were well behaved and were on } \\
\text { task and my mentor was really positive at the end }\end{array}$ \\
\hline Physiological and affective states (PAS) & $\begin{array}{l}\text { I also realise that I could have just stopped them half } \\
\text { way through and just reiterated those instructions. } \\
\text { But I was, kind of, too scared to do that at that } \\
\text { point }\end{array}$ \\
\hline \multicolumn{2}{|l|}{ Factors } \\
\hline Personal characteristics (having high expectations) & $\begin{array}{l}\text { I have higher expectations of myself, 'cause I had } \\
\text { good lessons, and therefore when I haven't, kind of, } \\
\text { had close to one of the best lessons I've had so far, } \\
\text { I feel like I'm failing }\end{array}$ \\
\hline Time & $\begin{array}{l}\text { It's just the time. I can make some really straightfor- } \\
\text { ward lessons really quickly but there just wouldn't } \\
\text { be much to them. And they will be really boring and } \\
\text { not that good }\end{array}$ \\
\hline Identity-related & $\begin{array}{l}\text { Because I'm a trainee [teacher], classroom manage- } \\
\text { ment is probably the aspect I'm least confident at } \\
\text { being able to do effectively }\end{array}$ \\
\hline
\end{tabular}

data (examples of which are presented in Table 2). Secondly, it required a review of current literature on the aspect relating specifically to the study-naming a role of teacher identity in TSE development. The results of the two moves enabled the analysis of the role of Katie's identities in the process of her TSE appraisal, presented in this article.

All coding and analysis were verified by another researcher who was familiar with data. This took place in way of closely following the analytical process, which allowed for questioning, clarifying and rectifying any arising discrepancies.

\section{Findings}

Katie's TSE development evolved "in a very non-linear way" (Katie), frequently fluctuating between confidence and doubts in her abilities as a competent teacher. Aligning with the posits of self-efficacy theory, it was evident that Katie's TSE was developing on the basis of information from the four self-efficacy sources. Yet, what was also evident was how little bearing those had on this development. This was particularly surprising since many of Katie's enactive experiences were considered successful (judged by the mentor's 
Table 2 Examples of coding of the data related to identity

\begin{tabular}{lc}
\hline Code example & Expression \\
\hline $\begin{array}{l}\text { Identity } \\
\text { Identification (cognitive appraisal) }\end{array}$ & $\begin{array}{c}\text { I look too young. I'm not like... yeah, not like a normal } \\
\text { teacher }\end{array}$ \\
Identification (reflected appraisal) & I'm worried they'll not see me or respect me as a teacher \\
Social verification (verbal) & Unfortunately, one student asked whether I was at sixth \\
& form, which didn't help my anxiety about coming across \\
& too young \\
Social verification (through social interaction) & I think the main thing was, just, kind of, interacting with the \\
& pupils more. (...) When they're talking to you and they see \\
& you as a person ... and accept you as a teacher, as well, \\
& which is quite nice \\
And in a way I guess making the plans my own makes it & look like I'm more of a competent teacher
\end{tabular}

frequent lesson feedback and by observations conducted as part of the study). Despite those, Katie continued to experience doubts in her ability to execute her particular teaching actions. Over the course of the year, what was becoming apparent was that Katie's TSE appraisal was affected by how she identified herself at particular moments of her training (as a student teacher or a teacher). The findings focus on illustrating this effect.

Of key importance in the findings was the way in which Katie viewed herself and viewed those who were teachers. That is since the authoring of her role identity, and consequently TSE, related to the comparisons that Katie made between the kind of person she was aspiring to be (what she understood it meant to be a teacher) and the kind of person she presently was; the comparison which frequently exposed discrepancies that led to negative emotions, inability to act effectively and raising doubts in Katie's capabilities.

In Katie's view teachers were individuals who were confident and authoritative, and who were able to portray their confidence in the classroom. Yet, she saw herself as "young", "quiet", "shy" and "disliking confrontations"-characteristics which she saw as being at odds with the image of her aspired future self. Indeed, Katie often explicitly referred to herself as "looking not like real teachers". These characteristics, reaffirmed by a student mistaking Katie for a fellow pupil, supported her strong student teacher identity.

Although such an identification might not be surprising considering the position that Katie was in (she was indeed a student teacher), it was important to consider in terms of how Katie acted upon it in her efforts to transition towards becoming a teacher. Katie had a particular idea of what it meant to be a student teacher. First, being a student teacher meant a potential lack of respect from students, who would not see her as a person of authority. Secondly, being a student teacher meant that there were things that she was not able to do. For example, although over the course of the year Katie expected to be teaching students and developing her skills related to that teaching, she also expected that she would be limited in her ability to do so autonomously. As a student teacher, she was unsure which routines and teaching styles she could or should engage with in the classroom, which meant that she often resorted to imitating other teachers' styles, seeing this as an opportunity to portray herself looking as "normal teachers". Yet this approach was often associated with a kind of stage performance, which for Katie who "was never very good at drama or acting", seemed like a difficult task. Consequently, Katie saw herself as unable to execute teacher 
actions effectively, reaffirming the discrepancy between herself and "real teachers". Collectively, these discrepancies between her actual and designated selves were frequently giving rise to negative emotions, which appeared to be ever-present in Katie's journey throughout the year.

A transition towards developing Katie's teacher identity related to several aspects, such as: sustained successful autonomous role enactment, an acceptance of her as a teacher colleague and a social verification of her as a teacher by students. Importantly, what was evident over the course of the year was that all three aspects of her identity formation were necessary to take place in order for Katie's teacher identity to start emerging. Yet the emergence of those was relatively slow, especially as far as the social verification aspect was concerned, which meant that Katie's teacher identity continued to be in a state of flux, even when she qualified as a teacher at the end of the year.

These identity struggles continued to influence the way that Katie appraised her TSE over the year. In what follows, is the illustration of this influence, considered in relation to two particular domains: behaviour management and responding to contingent situations in the classroom (including thinking on the spot and ability to deviate from a lesson plan).

\section{The role of student teacher identity in TSE appraisal}

At the start of the year, Katie experienced strong doubts in her ability to manage classroom behaviours and routines. Due to no prior enactive classroom experiences, which could have been assessed and reflected upon, Katie's TSE construction relied heavily on the way she identified herself as a student teacher. This related to her idealised view of what teachers should or do look like and a realisation that her own image did not correspond with this view.

Considering a specific image of a teacher, Katie, who had "only just came out of university", drew attention to two aspects of her character and appearance, which she saw as obstacles to becoming a teacher. First, she saw herself as a shy and quiet person, who would inevitably struggle to act confidently in the classroom. Describing herself she said:

I'm not, kind of, the loudest person (...) I look not that confident. I was never very good at drama or acting. Yeah... I am nervous about not being able to portray confidence or strength.

In addition to that, Katie saw herself as looking "very young", which had a direct effect on how she imagined her future ability to manage student behaviour. Katie emphasised how other teachers in the school were "quite a bit older" than her, making her "feel like a relative child" and as if she "was on a work experience". She frequently proclaimed her "anxiety about coming across too young and being able to have a presence of authority in a classroom". Although she started the year being eager to teach, Katie worried about her ability to confidently stand in front of and manage students. In her first interview, she said:

KATIE: I do not know how I will be able to manage the students. ... students not respecting me as a teacher because I look very young ... scares me.

INTERVIEWER: Why would they not respect you?

KATIE: I look too young. I'm not like... not like normal teachers.

In this exchange, we observe Katie using reflected appraisal, expecting students to see her as looking "very young" and "not like normal teachers", giving rise to strong negative emotions. This affected her view of her own competence in being able to manage students. 
Negative emotions related to the student identity, were also surfacing during Katie's early vicarious experiences at the start of the year. When comparing herself to an experienced teacher, whom she observed in the second week of the academic year, Katie expressed doubts in her future capabilities as a classroom manager. Describing it, Katie said:

It's interesting seeing classes misbehave with experienced teachers and thinking: 'God, that's gonna be, might be even worse for me because I'm just a trainee new teacher and they [students] will be able to see that'... How will I control them?

In this expression, we can see how the vicarious experience enabled a reflective comparison between Katie and the experienced teacher. Based on that, Katie articulated her worries about pupils misbehaving for her, purely because of who she was. These worries contributed negatively to her TSE appraisal, resulting in Katie pronouncing her doubts about her ability to "control" students in the near future.

In the third week of the school placement the negative emotions grew considerably as a result of Katie's interaction with a pupil, who mistook her for a fellow student. Katie recalled:

Unfortunately, one student asked whether I was at sixth form, ${ }^{1}$ which didn't help my anxiety about coming across too young, being able to have a presence of authority in a classroom and manage students.

Katie explained how this social verification exacerbated her anxiety about "coming across too young", immediately negatively affecting her belief about her ability to retain authority and to manage student behaviour in the future.

The accumulation of negative emotions related to her student identity began to affect Katie's experiences in the classroom. Although when working with younger students Katie began to grow in confidence in her ability to manage behaviour (explaining that those students were "THAT MUCH YOUNGER" (Katie's emphasis), made her feel like a "relative adult" and did "not intimidate" her), when interacting with older students, Katie found them "intimidating because they [students] are a bit older". This led to her experiencing a "mental block", which paralysed Katie's ability to act:

I'm really struggling to get over this mental block I have with telling OLDER students off. I just keep trying to avoid confronting them and escalating the consequences of their actions.

In this contrast between interacting with older and younger students we observe a direct effect of Katie's identity on inhibiting her actions. Katie recognised that in the presence of students who were closer to her in age she did not feel like an adult, which meant that she was simply unable to act in ways which would allow her to manage their behaviour effectively.

These struggles continued to affect Katie throughout the first half of the year. That was despite a growing accumulation of enactive experiences in the classroom, many of which reported Katie's successes with managing student behaviour. Both the lesson reports written by Katie's school mentor and the first three lesson observations undertaken as part of the study revealed Katie's effectiveness in managing classroom

1 Sixth Form-final two years of an English upper secondary school. 
behaviour. Yet, these successful enactive experiences were proving insufficient for Katie's construction of her competent self-view. In the fourth interview of the year Katie explained why, in her opinion, she continued to struggle with this. She said:

Probably because I'm a trainee [teacher], classroom management is probably the aspect I'm least confident at being able to do effectively... I just get worried that the students won't listen. ... For some reason the idea of telling students off is nerve-wracking-I'm worried they'll not see me or respect me as a teacher, ignore what I'm saying and I'll lose all sense of authority.

This reflection illustrates how, based on her own identification and a reflected appraisal of herself as a student teacher, Katie found the very "idea of telling students off ... nerve-wracking", which paralysed her actions and which trapped her in the doubtful view about her competence in managing classrooms effectively.

Katie's worries about her expectations of how students would behave in the presence of a student teacher might be linked to how she understood what it meant to be a student teacher. In Katie's eyes, being a student teacher meant taking over classes that "belong to other teachers", which limited her autonomy in her own actions. As a result, since she considered that she was “coming into this other person's car so I don't want to change things up", Katie often found herself "adopting other teachers' styles" in her teaching. It is important to point out that there was no external expectation for Katie to be engaging in such an imitative behaviour. In fact, it was Katie herself who saw adherence to other teachers' routines as a way of legitimising herself as a teacher in the eyes of her students, emphasising that "the less difference there is [between her and the classroom teacher] ... the more legitimate [she would] feel". Despite this belief, however, the imitative behaviour affected Katie's ability to act effectively. First, it prevented her from establishing her own authority with the students. Katie said:

What is hard for me, definitely, [is] establishing my authority in the classroom and managing students. I think it's particularly hard in a placement school when it's always a teacher's class, you coming in and you trying to take over as a trainee teacher. You can't, kind of, set your own routines or if you are it's going to be lots harder.

Here, we begin to see how Katie considered her specific role of a student teacher to be limiting in what she felt she could do and achieve, when teaching other teachers' classes. Even if she understood that one of the ways to develop as a competent teacher was to enact the teacher role, in her current circumstance Katie did not yet see such an enactment as feasible or easy to execute.

Secondly, employing "other teachers' styles" affected Katie's ability to act in the moment, making her "losing the thread of what I'm saying, getting flustered and not making much sense to anyone" or affecting her ability to "develop flexibility in a lesson plan on the spot" when such was necessary. Consequently, this struggle to perform effectively in the classroom, had a negative effect on Katie's perceived ability to manage student behaviour as well as her ability to explain concepts or respond to contingent situations in the classroom.

Having struggled with this issue for several weeks, Katie eventually reached a decision that breaking away from this unspoken arrangement, whereby she had tried to adopt other teachers' classroom routines, should be the first step in gaining more confidence in her actions. Six weeks before the end of the school experience Katie explained: 
I think what I might do next week, after talking to the class teacher, is completely break with her lesson format so I don't feel like I am trying to imitate her way of teaching and then I might feel more comfortable.

This reflection indicates a pivotal point in Katie's actions towards transitioning between her student teacher and teacher identities. Following continuous struggles, which were affected by Katie's ongoing efforts to imitate the classroom teacher's specific routines, Katie faced the necessity to change her approach. After a conversation with the classroom teacher, she finally accepted the idea of breaking away from the imitative behaviour and planned to initiate an exercise of her own autonomy, with hope that this would lead to more comfort and, consequently, success in the classroom.

\section{The role of emerging teacher identity in TSE appraisal}

The decision to start introducing her own routines represented a significant turning point in Katie's development of her TSE, where she initiated a transition in its appraisal from a rather limiting focus on what she looked like (very young) and who she was (a student teacher) towards who she wanted to become (a teacher) and, consequently, how she needed or wanted to act (i.e. "do what teachers do"). In other words, Katie began to refocus her identity attention from factors that were beyond her control (i.e. looking young), towards aspects she could act upon, such as: developing social interactions and building relationships with students (which could help verify her emerging teacher identity), and autonomous teacher role enactment (which should help her begin to realise her teacher identity). This refocus contributed to decreasing Katie's emotional arousal, allowing her to focus on her performance and to begin to view her developing competence in a more positive light.

When discussing her changing TSE Katie emphasised the importance of the process of realising her teacher role identity through the teacher role enactment. She explained how opportunities to plan her own lessons in her own way made her look like a competent teacher, consequently making her feel that she could teach well. Katie said:

In a way I guess making the plans my own makes it look like I'm more of a competent teacher than when I'm just, kind of, copying what their teacher does. Then I can teach well and explain things well.

These opportunities to fully enact her teacher role translated into Katie's growing confidence in her own competence. The above excerpt represents one of the first expressions in which Katie made explicit comments about her growing feeling that she could finally teach and explain things well. Although in TSE theory's terms one could argue that this change in Katie's view about her own competence resulted simply from mastery experiences, Katie clearly emphasised how it was not the sheer act of doing but rather the effect that the autonomous realisation of her teacher role had on that doing which bore the most significance. Katie felt that she was able to be effective in the classroom as a result of fully enacting her teacher role which made her "look like ... more of a competent teacher". Such can be seen as connected to Katie's developing identity as a teacher through both her own experiencing of her actions and her own perception of the public view of herself in her role.

In the final interview of the year, Katie emphasised further how taking responsibility for teaching whole lessons made her feel "more in place" and, consequently, more effective. She said: 
I think doing the whole lesson was better in that sense, 'cause you didn't have to hand over to the teacher and you felt more in control and more in place. This gave me confidence in being able to run the lesson effectively.

In those words Katie emphasised the important role that both acting and feeling legitimate as a teacher played in her perception of her ability to act competently and, as a result, to construct a view of herself as a competent professional. It was important for Katie that students would see her enacting her teacher role fully, as any other teacher would, which would help validate her teacher role. Moreover, the planning and executing her own lessons fully, made her feel more in control, which contributed to the effectiveness of the enactive experiences.

In addition to the role enactment, social verification of Katie's identity also played a significant role in her TSE development. At the start of the year, Katie was full of anticipation about how she would be treated in her role by other teachers in the mathematics department. Having moved to her second school placement, Katie was relieved to feel accepted by the teachers she was working with, who she said were "really supportive", and who treated Katie as a colleague and not as if she "was an extra kind of annoying person to get around". This acceptance as a colleague teacher played a big part in how Katie judged her ability to perform specific teacher actions. In responding to a question about factors playing the greatest role in her TSE development, Katie said that "talking to other teachers" and becoming an accepted part of the teacher community provided a boost in her confidence in her capabilities. She explained:

Once I've been on the block [second] placement, I've had much more chance to, kind of, develop and talk to other teachers more and get to know them. And that was nice. Just that community really, just made me feel more, kind of, in place in the school and made me not to feel so on the outside and that, in a way, somehow affected my confidence ‘cause I didn't feel like an annoyance but more like a teacher. This really helped me feel more confident about being able to teach and manage students.

Katie emphasised that the role of social verification of her as a teacher was also expressed through her developing relationships with students, which she saw as students' gradual acceptance of her as a teacher:

I think the main thing was, just, kind of, interacting with the pupils more. ... And it's actually when they ask me questions or they just talk to me, that's quite nice 'cause it actually feels like 'ok, they don't... not, kind of, resenting me being here in the classroom'. ... When they're talking to you and they see you as a person ... and accept you as a teacher, as well, which is quite nice. So, developing that kind of relationship with the students has definitely helped build my confidence in being able to stand in front of them and teach them well.

We can see here that the social verification of Katie as a teacher was particularly significant in influencing her confidence in the classroom which, as she extrapolated, resulted in her growing belief in her ability to teach well. This indicates a clear shift in Katie's developing personal view of her competence. As Katie continued the year, she accumulated experiences both in and outside the classroom, and she continued to develop relationships with her colleagues and students. These experiences slowly took precedence over Katie's strong initial worries about looking too young or being seen as a student teacher in her emerging teacher identity. This led to a more confident role enactment and, as a result, helped Katie develop a stronger view of herself as a competent professional, which 
continued until Katie officially qualified as a teacher and started preparing for her first teaching job in the upcoming September.

\section{Qualifying as a teacher and TSE appraisal}

When discussing her overall experience on the course and the prospect of moving to a new school in September, despite having asserted progress in her developing TSE throughout the year, Katie once again expressed doubts in her ability to act competently and effectively in the classroom. As Katie explained, her "efficacy didn't necessarily translate too well across different teaching experiences". Despite the fact that she was now able to call herself a "qualified teacher" and considered herself not to "look too dissimilar to other teachers from the distance in front of the class", Katie expected her TSE to continue to be relatively unstable until a social verification of her teacher identity in the new context took place. Discussing her move to a new school in September, Katie explained how she worried about her ability to manage students in the new context due to an uncertainty of how she would be received by the new students. This exhibited similarities with the thoughts Katie had shared at the start of the academic year. Expressions such as "I don't know whether the students should respect me or not" were, once again, beginning to highly influence Katie's own image of her competence in the teacher role. Explaining this effect Katie said:

Thinking about being able to manage students, looking forward to next year, it is worrying ... the students getting to know me and that's probably what I'm most worried about, it's just the initial period with the kids assessing me and not seeing me as a teacher.

As can be seen, Katie ascribed her arising doubts about her ability to perform effectively to her yet-to-be-verified identity of a teacher. This social verification, which would help Katie reaffirm her developing teacher identity, appeared to play a significant role in her TSE appraisal at that point. That was despite the fact that, officially speaking, Katie was now no longer a student teacher.

\section{Discussion}

It has been posited before that the development of self as a competent teacher represents a dynamic system which encapsulates one's personality, identity and professional capacity (Smith, 2014), and that a clear self-image and ownership of an emerging professional identity are necessary conditions for a pre-service teacher's ability to effectively use their skills and knowledge in the classroom (Bennett, 2013). This suggests that TSE and teacher identity are inextricably connected in one process of self-development (Canrinus et al., 2012; Kelchtermans, 2009; van der Want, et al., 2019). Yet, studies in TSE development tend to focus predominantly on the role of four self-efficacy sources in this process (Glackin \& Hohenstein, 2018), leaving the relationship between TSE appraisal and teacher identity unexplored. This study begins to address this gap, by illustrating how a pre-service secondary mathematics teacher's identity affected the process of her TSE appraisal; and in particular how her prevalent student teacher identity undermined her TSE, and her emerging teacher identity supported this development (especially in the context of managing students' behaviour, planning and teaching successful lessons, explaining mathematical concepts or responding to contingent situations in the classroom). This direct effect of 
identity on TSE development was often explicitly described by Katie in expressions such as: "because I'm a trainee [teacher], classroom management is probably the aspect I'm least confident at", and continued throughout the year.

Katie's strong identification as a student teacher had a complex effect on her TSE appraisal. Identifying herself as a student teacher, Katie was often inclined to adhere to other teachers' routines and teaching styles, despite the fact that there was no expectation for her to do so. Considering the fact the narratives of one's identity are an important factor in one's actions (Sfard \& Prusak, 2005), Katie's imitative behaviour might not be surprising, since her own understanding of a student teacher role revolved around limited autonomy when "taking over other teachers' classes". Her adherence to "other teachers' styles", which is a commonplace in initial teacher education (Wang \& Odell, 2007), however, negatively affected Katie's ability to act confidently and effectively, increasing the sense of failure in her performance and, consequently, having a negative effect on her TSE appraisal.

Seeing herself as a student teacher also continued to give rise to negative emotions, which affected Katie's TSE appraisal (particularly when considering teaching older students). Although studies in mathematics teacher identity research have so far paid little attention to identity-related affect (Lutovac \& Kaasila, 2018), from the narrative perspective on identity we recognise emotions as inextricably connected to the process of change (Sfard \& Prusak, 2005). In the process of narrating, doubts and incongruencies in one's identity give can rise to uncertainty and anxiety (Archer, 2000; Bruner, 1990; Garner \& Kaplan, 2019; Sfard \& Prusak, 2005), which affect our ability to execute identity-associated actions (Benson, 2003). Such an effect is illustrated here. Katie frequently reflected on discrepancies between her current (student teacher) and aspiring (teacher) identities, by emphasising that she does not have the characteristics of (e.g. being confident) and does not look "like normal teachers". These struggles left Katie feeling intimidated and anxious, making her unable to act, which had a negative effect on her TSE appraisal.

It has been suggested before that with growing mastery experiences one would expect the significance of negative emotions in one's TSE development to weaken (Carter, 2013; Ruble et al., 2011). Yet, for Katie, the significant effect of identity-related emotions on her TSE continued throughout the year despite a vast accumulation of successful mastery experiences. This might be surprising considering the posits of TSE theory which often emphasise enactive mastery experiences to be the most significant source of TSE (Bong \& Skaalvik, 2003; Rutherford et al., 2017; Skaalvik \& Skaalvik, 2010; Usher \& Pajares, 2008), and the posits of identity theory, which argue that individuals boost their own selfimage through performing specific roles well (Stets \& Burke, 2000). In short, generally speaking, successful role enactment is seen to contribute to the development of one's designated identity and their TSE (Bong \& Skaalvik, 2003; Brenner et al., 2014; Stets \& Burke, 2000; Usher \& Pajares, 2008). What the case of Katie illustrates, however, is the necessity to consider these enactive experiences from a particular perspective. In order for enactive mastery experiences to be significant, they needed to authentically fulfil the expectations of the teacher role. As mentioned earlier, the prolonged imitative behaviour of other teachers' styles had an adverse effect on Katie, who consequently was unable to act competently in the classroom. This continued until Katie changed her approach, from imitative to more autonomous, in which she focused on setting up her own classroom routines and exploring her own teaching styles. This change played a pivotal role in Katie's development. Focusing more explicitly on devising her own lesson plans and setting her own routines and ways of teaching meant that Katie was no longer imitating other teachers but was rather "doing what other teachers do". This meant that she was able to redirect her focus from negative identity-related emotions towards enactive aspects of her teacher role which helped her 
improve her view of herself as a competent teacher and which had a positive effect on her TSE.

Previous studies advocated creating multiple opportunities for pre-service teachers to engage in enactive experiences early on in teacher education (Bates et al., 2011; Klassen \& Durksen, 2014). While this study supports this emphasis, it also points to the importance of considering the nature of those experiences. The case of Katie shows that, although enactive mastery experiences in imitating modelled behaviours, which are considered to be particularly powerful sources of TSE for pre-service teachers who lack extensive experience (Tschannen-Moran \& Woolfolk Hoy, 2007), can provide a stepping stone in the teachers' development within the profession, they need not remain of focus for prolonged periods of time. This is because the imitative nature of such experiences can interfere with the development of one's teacher identity which, consequently, might have an adverse effect on one's TSE appraisal. Instead, powerful enactive mastery experiences can be those which are authentic in the way in which they allow the pre-service teachers to enact their teacher role autonomously. This emphasis on autonomous actions is already evident in other studies in mathematics education which consider the process of identity construction and learning (e.g. Hodges \& Cady, 2012). In this study we see further implications of this for TSE development.

Importantly still, this study illustrates that effective teacher role enactment can also be highly affected by social verification of one's teacher identity, which can be expressed explicitly or through developing relationships with others (Pillen et al., 2013). Being accepted as a member of teacher community, developing relationships with and feeling accepted as a teacher by her students, made Katie feel more confident in her ability to enact her teacher role. This aspect of her emerging teacher identity was particularly significant when Katie considered her move to a new school as a qualified teacher in the following September. Then she appeared to experience a somewhat backwards shift in her TSE. Katie explained that in the new context she would not be able to appraise her TSE until she felt accepted as a teacher by the new community. It appeared, at that stage, that the accumulation of previous experiences, the positively developing view of her own competence and officially qualifying as a teacher were not sufficient for Katie to fully project her TSE onto her future experiences. Although this finding might not be surprising in the light of identity theory, which emphasises that important identities are in need of social verification (Sfard \& Prusak, 2005), it is significant to recognise its role in TSE development, as it suggests that TSE might continue to be negatively affected for at least as long as pre-service teachers (perhaps particularly those who are young) struggle to have their teacher identity verified within a particular community (Sfard \& Prusak, 2005). Such aspects might also help explain why, despite an early accumulation of enactive experiences, pre-service teachers' TSE could remain in a state of flux until their teacher identity becomes verified socially.

\section{Implications}

The results of the study contribute to extending our understanding of TSE development beyond the currently employed Bandura's four-source framework (Glackin \& Hohenstein, 2018), by discussing the role of teacher identity in this process. Although studies in mathematics TSE to date emphasise the significance of time in TSE development (e.g. Kim et al., 2014) and illustrate that this development follows different trajectories for different individuals (Charalambous et al., 2008), they do not discuss these findings 
in connection to teacher identity. Yet, similarly to the work of Moslemi and Habibi (2019), this study illustrates that the identity perspective on learning and development helps explain at least some aspects of the process of TSE appraisal. Considering the fact that teacher identity and TSE are a part of one dynamic concept of self (Canrinus et al., 2012; Day \& Gu, 2007; Kelchtermans, 2009), separating the two in one process of becoming seems like a significant omission. The scarcity of such research in the field of education, and mathematics education in particular, needs to be addressed. Such efforts could include quantitative correlative studies such as that of Moslemi and Habibi (2019) or qualitative studies which take a closer look at the process of meaning-making in the narrative construction of self (see Marschall \& Watson, forthcoming).

The findings of the study have also further implications for conceptualising mathematics teacher education which tends to overestimate the importance of subject knowledge and beliefs over other aspects of teachers' development (Leder, 2007). That is, of course, not to say that teacher knowledge is not important. Indeed, research is ubiquitous in evidence showing how enhancing teachers' knowledge can have a positive impact on teachers' identity development and their feeling of readiness for teaching (e.g., Bates et al., 2011; Hossain et al., 2013; Newton et al., 2012). This is rather to emphasise that strong subject knowledge does not necessarily protect teachers from experiencing doubts in their ability to act effectively in the classroom (McCampbell, 2015; Zee \& Koomen, 2016). Many of those doubts, as Katie's case clearly illustrates, can relate to the discrepancies between who teachers see themselves to be and the image of a teacher they aspire towards which, although somewhat natural, is an emotionally difficult aspect of the narrative process of becoming (Archer, 2000; Sfard \& Prusak, 2005). Understandably, it is in the interest of teacher educators to help mitigate those high affective states, if possible.

The study emphasises that teacher professional development activities need to recognise a multidimensionality of teacher learning, which is individual, enactive, emotional and social (Marschall \& Watson, 2019). Although such a perspective is already incorporated in the theoretical perspective of TSE (Bandura, 1997), factoring teacher identity in this development, sheds further light on these dimensions. The case of Katie illustrates that all three aspects of her professional identity (being a particular kind of person, role enactment and social verification) as well as associated affective arousal were necessary to consider in order for her teacher identity to start emerging and her TSE to be appraised positively. Considering this, any teacher professional development agenda needs to necessarily attend to all of those aspects, by providing pre-service teachers with frequent opportunities for autonomous identity-related enactive mastery experiences (Wang \& Odell, 2007) and for developing long-lasting relationships with students and teacher colleagues (Pillen et al., 2013).

In this respect, I suggest, our practical treatment of identity in the current political educational culture must also come under scrutiny. The current educational context in England continues to emphasise "performativity" of the profession and judges teachers by how much they "know" and how they perform under strictly prescribed criteria (Ball, 2003). In such context, identifying oneself as a student teacher might seem somewhat undesirable, exacerbating the pressure for teachers to portray themselves as experts. Consequently, it is not unreasonable to expect that student teachers, who chase the expectation of becoming "an expert teacher" by the end of their initial teacher education, will continue to experience high levels of negative emotions associated with the understandably existent discrepancies between who they are and the teachers they one day wish to become (Sfard \& Prusak, 2005). 
Moreover, such an approach also encourages a static view of identity-something that one achieves as opposed to something that one continues to cultivate throughout their career. I suggest that openly accepting our trainee teachers (as they are sometimes referred to) as our pre-service colleagues, supporting them in seeing their emerging teacher identity as a dynamic process of becoming, and allowing them to fully embrace the process of development as opposed to achievement, are of key importance in helping to mitigate these high emotions and uncertainties. For this to take place, however, we must also relief our inservice teachers from the pressures of performativity and allow them to embrace the idea that being a student and being a teacher are not mutually exclusive (Burn et al., 2015), but rather that they are both part of one life-long narrative process of becoming.

\section{Limitations}

Finally, it seems important to reflect on the fact that, although throughout the year the preservice teacher in this study was concerned with a wide variety of aspects related to teaching, classroom management domain appeared to be of her particular focus. Based on my work with many pre-service secondary mathematics teachers over the last decade, this did not seem unusual. Important to emphasise here, however, might be the aspect of the preservice teacher's strong subject knowledge, which was a pre-requisite for the admission to this particular ITE programme. It is perhaps possible, as it has been shown in previous studies (e.g. Stevens et al., 2013), that classroom management preoccupation is more common among teachers with stronger subject knowledge, when compared with their colleagues who consider themselves lacking such knowledge. Hence, it is not unreasonable to expect that teachers of different academic profiles might show different domain preoccupation at different times of their education.

Acknowledgements I would like to thank my supervisors Eva Norén, Kerstin Pettersson and Steve Watson, my colleagues from the SOCAME group as well as Aurel Diamond and Prof. Tim Rowland for providing helpful comments on the drafts of this article.

Funding Open access funding provided by Stockholm University. This research was supported by the Department of Mathematics and Science Education, Stockholm University, Sweden, and the Faculty of Education, University of Cambridge, UK.

\section{Declarations}

Conflict of interest The author declares that she has no conflict of interest.

Open Access This article is licensed under a Creative Commons Attribution 4.0 International License, which permits use, sharing, adaptation, distribution and reproduction in any medium or format, as long as you give appropriate credit to the original author(s) and the source, provide a link to the Creative Commons licence, and indicate if changes were made. The images or other third party material in this article are included in the article's Creative Commons licence, unless indicated otherwise in a credit line to the material. If material is not included in the article's Creative Commons licence and your intended use is not permitted by statutory regulation or exceeds the permitted use, you will need to obtain permission directly from the copyright holder. To view a copy of this licence, visit http://creativecommons.org/licenses/by/4.0/. 


\section{References}

Adams, C. M., \& Forsyth, P. B. (2006). Proximate sources of collective teacher efficacy. Journal of Educational Administration, 44(6), 625-642.

Aloe, A. M., Amo, L. C., \& Shanahan, M. E. (2014). Classroom management self-efficacy and burnout: A multivariate meta-analysis. Educational Psychology Review, 26(1), 101-126.

Alrajhi, M., Aldharfi, S., Alkharusi, H., Albusaidi, S., Alkharusi, B., Ambusaidi, A., \& Alhosni, K. (2017). The predictive effects of math teachers' emotional intelligence on their perceived self-efficacy beliefs. Teaching and Teacher Education, 67, 378-388.

Archer, M. (2000). Being human: The problem of agency. Cambridge University Press.

Ball, S. J. (2003). The teacher's soul and the terrors of performativity. Journal of Education Policy, 18(2), 215-228.

Bandura, A. (1997). Self-efficacy: The exercise of control. W. H. Freeman and Company.

Bandura, A. (2006). Toward a psychology of human agency. Perspectives on Psychological Science, 1(2), 164-180.

Bates, A. B., Latham, N., \& Kim, J. (2011). Linking preservice teachers' mathematics self-efficacy and mathematics teaching efficacy to their mathematical performance: Linking preservice teachers. School Science and Mathematics, 111(7), 325-333.

Beijaard, D., Meijer, N. P. C., \& Verloop, N. (2004). Reconsidering research on teachers' professional identity. Teaching and Teacher Education, 20(2), 107-128.

Bennett, D. (2013). The use of learner-generated drawings in the development of music students' teacher identities. International Journal of Music Education, 31(1), 53-67.

Benson, C. (2003). The unthinkable boundaries of self: The role of negative emotional boundaries in the formation, maintenance, and transformation of identities. In R. Harré \& F. Moghaddam (Eds.), The self and the others (pp. 61-84). Praeger Publishers.

Bong, M., \& Skaalvik, E. M. (2003). Academic self-concept and self-efficacy: How different are they really? Educational Psychology Review, 15(1), 1-40.

Brenner, P. S., Serpe, R. T., \& Stryker, S. (2014). The causal ordering of prominence and salience in identity theory: An empirical examination. Social Psychology Quarterly, 77(3), 231-252.

Bruner, J. (1990). Acts of meaning. Harvard University Press.

Burke, P. J., \& Stets, J. E. (1999). Trust and commitment through self-verification. Social Psychology Quarterly, 62, 347-366.

Burn, K., Hagger, H., \& Mutton, T. (2015). Beginning teachers' learning: Making experience count. Critical Publishing Ltd.

Canrinus, E. T., Helms-Lorenz, M., Beijaard, D., Buitink, J., \& Hofman, A. (2012). Self-efficacy, job satisfaction, motivation and commitment: Exploring the relationships between indicators of teachers' professional identity. European Journal of Psychology of Education, 27, 115-132.

Carter, M. J. (2013). Advancing identity theory: Examining the relationship between activated identities and behavior in different social contexts. Social Psychology Quarterly, 76(3), 203-223.

Chacón, C. T. (2005). Teachers' perceived efficacy among English as a foreign language teachers in middle schools in Venezuela. Teaching and Teacher Education, 21(3), 257-272.

Charalambous, Y. C., Philippou, G. N., \& Kyriakides, L. (2008). Tracing the development of preservice teachers' efficacy beliefs in teaching mathematics during fieldwork. Educational Studies in Mathematics, 67(2), 125-142.

Cheung, H. Y. (2008). Teacher efficacy: A comparative study of Hong Kong and Shanghai primary inservice teachers. The Australian Educational Researcher, 35(1), 103-123.

Cochran-Smith, M., Ell, F., Ludlow, L., Grudnoff, L., \& Aitken, G. (2014). The challenge and promise of complexity theory for teacher education research. Teachers College Record, 116(5), 1-38.

Cohen, L., Manion, L., \& Morrison, K. (2011). Research Methods in Education (7th edition). Routledge.

Collie, R. J., Shapka, J. D., \& Perry, N. E. (2012). School climate and social-emotional learning: Predicting teacher stress, job satisfaction, and teaching efficacy. Journal of Educational Psychology, 104(4), 1189-1204.

Côté, J. E., \& Levine, C. G. (2014). Identity formation, agency, and culture. Lawrence Erlbaum Associates Publishers.

Craft, A., Hall, E., \& Costello, R. (2014). Passion: Engine of creative teaching in an English university? Thinking Skills and Creativity, 13, 91-105.

Czerniawski, G. (2011). Emerging teachers-emerging identities: Trust and accountability in the construction of newly qualified teachers in Norway, Germany, and England. European Journal of Teacher Education, 34(4), 431-447. 
Darragh, L. (2016). Identity research in mathematics education. Educational Studies in Mathematics, 93, 19-33.

Darragh, L., \& Radovic, D. (2019). 'To Tia with love': Chilean mathematics teacher identities after professional development. ZDM, 51, 517-527.

Davis, J. L., Love, T. P., \& Fares, P. (2019). Collective Social Identity: Synthesizing identity theory and social identity theory using digital data. Social Psychology Quarterly, 82(3), 254-273.

Day, C., \& Gu, Q. (2007). Variations in the conditions for teachers' professional learning and development: Sustaining commitment and effectiveness over a career. Oxford Review of Education, 33(4), 423-443.

Ekstam, U., Korhonen, J., Linnanmaki, K., \& Aunio, P. (2017). Special education pre-service teachers' interest, subject knowledge, and teacher efficacy beliefs in mathematics. Teaching and Teacher Education, 63, 338-345.

Flores, M. A., \& Day, C. (2006). Contexts which shape and reshape new teachers' identities: A multiperspective study. Teaching and Teacher Education, 22, 219-232.

Garner, J., \& Kaplan, A. (2019). A complex dynamic systems perspective on teacher learning and identity formation: An instrumental case. Teachers and Teaching, 25(1), 7-33.

Glackin, M., \& Hohenstein, J. (2018). Teachers' self-efficacy: Progressing qualitative analysis. International Journal of Research \& Method in Education, 41(3), 271-290.

Graven, M., \& Heyd-Metzuyanim, E. (2019). Mathematics identity research: The state of the art and future directions. ZDM Mathematics Education 51, 361-377. https://doi.org/10.1007/s11858-019-01050-y

Gresham, G. (2007). A study of mathematics anxiety in pre-service teachers. Early Childhood Education Journal, 35(2), 181-188.

Gresham, G. (2008). Mathematics anxiety and mathematics teacher efficacy in elementary pre-service teachers. Teaching Education, 19(3), 171-184.

Hamman, D., Gosselin, K., Romano, J., \& Bunuan, R. (2010). Using possible-selves theory to understand the identity development of new teachers. Teaching and Teacher Education, 26, 1349-1361.

Hodges, T. E., \& Cady, J. A. (2012). Negotiating contexts to construct an identity as a mathematics teacher. The Journal of Educational Research, 105(2), 112-122.

Holzberger, D., Philipp, A., \& Kunter, M. (2013). How teachers' self-efficacy is related to instructional quality: A longitudinal analysis. Journal of Educational Psychology, 105(3), 774-786.

Hong, J. Y. (2010). Pre-service and beginning teachers' professional identity and its relation to dropping out of the profession. Teaching and Teacher Education, 26, 1530-1543.

Hossain, S., Mendick, H., \& Adler, J. (2013). Troubling "understanding mathematics in-depth": Its role in the identity work of student-teachers in England. Educational Studies in Mathematics, 82, 35-48.

James-Wilson, S. (2001). The influence of ethnocultural identity on emotions and teaching. In Paper presented at the Annual Meeting of the American Educational Research Association. New Orleans.

Katz, P., McGinnis, J. R., Hestness, E., Riedinger, K., Marbach-Ad, G., Dai, A., \& Pease, R. (2011). Professional identity development of teacher candidates participating in an informal science education internship: A focus on drawings as evidence. International Journal of Science Education, 33(9), 1169-1197.

Kelchtermans, G. (2009). Teachers' emotions in educational reforms: Self-understanding, vulnerable commitment and micropolitical literacy. Teaching and Teacher Education, 21, 995-1006.

Kim, R., Sihn, H. G., \& Mitchell, R. (2014). South Korean elementary teachers' mathematics teaching efficacy beliefs implications for educational policy and research. Mathematics Education Trends and Research, 2014, 1-17.

Klassen, R. M., Bong, M., Usher, E. L., Chong, W. H., Huan, V. S., Wong, I. Y. F., \& Georgiou, T. (2009). Exploring the validity of a teachers' self-efficacy scale in five countries. Contemporary Educational Psychology, 34(1), 67-76.

Klassen, R. M., \& Chiu, M. M. (2010). Effects on teachers' self-efficacy and job satisfaction: Teacher gender, years of experience, and job stress. Journal of Educational Psychology, 102(3), 741-756.

Klassen, R. M., \& Durksen, T. L. (2014). Weekly self-efficacy and work stress during the teaching practicum: A mixed methods study. Learning and Instruction, 33, 158-169.

Labone, E. (2004). Teacher efficacy: Maturing the construct through research in alternative paradigms. Teaching and Teacher Education, 20(4), 341-359.

Leder, G. C. (2007). Beliefs: What lies behind the mirror? The Montana Council of Teachers of Mathematics, 3, 39-50.

Long, J., \& Woolfol Hoy, A. (2006). Interested instructors: A composite portrait of individual differences and effectiveness. Teaching and Teacher Education, 22(3), 303-314.

Lutovac, S., \& Kaasila, R. (2018). Future directions in research on mathematics-related teacher identity. International Journal of Science and Mathematics Education, 16, 759-776. 
Marschall, G., \& Watson, S. (2019). Social cognitive theory as an integrated theory of mathematics teachers' professional learning. Proceedings from the Conference of the International Group for Psychology of Mathematics Education, PME43, University of Pretoria, South Africa. https://doi.org/10.17863/ CAM.38991

Marschall, G., \& Watson, S. (forthcoming). Teacher self-efficacy as an aspect of a narrative self-schema.

McCampbell, S. (2015). Pre-service teachers' self-efficacy for teaching mathematics [Doctor of Philosophy unpublished dissertation]. Retrieved from https://digitalrepository.unm.edu/educ_ifce_etds/28

Monrouxe, L. V., Rees, C. E., \& Hu, W. (2011). Differences in medical students' explicit discourses of professionalism: Acting, representing, becoming. Medical Education, 45, 585-602.

Morris, D. B., Usher, E. L., \& Chen, J. A. (2017). Reconceptualizing the sources of teaching self-efficacy: A critical review of emerging literature. Educational Psychology Review, 29(4), 795-833.

Moslemi, N., \& Habibi, P. (2019). The relationship among Iranian EFL teachers' professional identity, selfefficacy and critical thinking skills. HOW, 26(1), 107-128.

Neubauer, B. E., Witkop, C. T., \& Varpio, L. (2019). How phenomenology can help us learn from the experiences of others. Perspectives on Medical Education, 8, 90-97.

Newton, K., Evans, B., Leonard, J., \& Eastburn, J. (2012). Preservice elementary teachers' mathematics content knowledge and teacher efficacy. School Science and Mathematics, 112(5), 289-299.

Nie, Y., Tan, G. H., Liau, A. K., Lau, S., \& Chua, B. L. (2013). The roles of teacher efficacy in instructional innovation: Its predictive relations to constructivist and didactic instruction. Educational Research for Policy and Practice, 12(1), 67-77.

Philippou, G. N., \& Pantziara, M. (2015). Developments in mathematics teachers' efficacy beliefs. In B. Pepin, \& B. Roesken-Winter (Eds.), From beliefs to dynamic affect systems in mathematics education (pp. 95-117). Springer International Publishing. https://doi.org/10.1007/978-3-319-06808-4_5

Pillen, M., Beijaard, D., \& den Brok, P. (2013). Tensions in beginning teachers' professional identity development, accompanying feelings and coping strategies. European Journal of Teacher Education, 36, $240-260$.

Platt, J. (1988). What can case studies do? In R. G. Burgess (Ed.), Studies in qualitative methodology: A research annual. Conducting qualitative research. (Vol. 1). JAI Press.

Poulou, M. (2007). Personal teaching efficacy and its sources: Student teachers' perceptions. Educational Psychology, 27(2), 191-218.

Ruble, L. A., Usher, E. L., \& McGrew, J. H. (2011). Preliminary investigation of the sources of self-efficacy among teachers of students with autism. Focus on Autism and Other Developmental Disabilities, 26(2), 67-74.

Rutherford, T., Long, J. J., \& Farkas, G. (2017). Teacher value for professional development, self-efficacy, and student outcomes within a digital mathematics intervention. Contemporary Educational Psychology, 51, 22-36.

Sfard, A. (2019). Making sense of identities as sense-making devices. ZDM Mathematics Education, 51, $555-564$.

Sfard, A., \& Prusak, A. (2005). Telling identities: In search of an analytic tool for investigating learning as culturally shaped identity. Educational Researcher, 34(4), 14-22.

Sinclair, B. B., Naizer, G. L., \& Ledbetter, C. (2011). Observed implementation of a science professional development program for K-8 classrooms. The Journal of Elementary Science Education, 22, 579-594.

Skaalvik, E. M., \& Skaalvik, S. (2007). Dimensions of teacher self-efficacy and relations with strain factors, perceived collective teacher efficacy, and teacher burnout. Journal of Educational Psychology, 99(3), 611-625.

Skaalvik, E. M., \& Skaalvik, S. (2010). Teacher self-efficacy and teacher burnout: A study of relations. Teaching and Teacher Education, 26, 1059-1069.

Smith, J. A., Flower, P., \& Larkin, M. (2009). Interpretative Phenomenological Analysis: Theory, methodology and research. SAGE Publications Inc.

Smith, J. D. (2014). Self-concept: Autopoiesis as the basis for a conceptual framework. Systems Research and Behavioral Science, 31, 32-46.

Soini, T., Pietarinen, J., Toom, A., \& Pyhältö, K. (2015). What contributes to first-year student teachers' sense of professional agency in the classroom? Teachers and Teaching, 21(6), 641-659.

Stets, J. E., \& Burke, P. J. (2000). Identity theory and social identity theory. Social Psychology Quarterly, 63(3), 224-237. https://doi.org/10.2307/2695870

Stevens, T., Aguirre-Munoz, Z., Harris, G., Higgins, R., \& Liu, X. (2013). Middle level mathematics teachers' self-efficacy growth through professional development: Differences based on mathematical background. Australian Journal of Teacher Education, 38(4), 144-164.

Stryker, S., \& Burke, P. J. (2000). The past, present, and future of an identity theory. Social Psychology Quarterly, 63(4), 284-297. 
Tavory, I., \& Timmermans, S. (2014). Abductive analysis. The University of Chicago Press Ltd.

Thompson, M., DiFrancesca, D., Carrier, S., \& Lee, C. (2017). Teaching efficacy: Exploring relationships between mathematics and science self-efficacy beliefs, PCK and domain knowledge among preservice teachers from the United States. Teacher Development, 21(1), 1-20.

Thurlings, M., Evers, A. T., \& Vermeulen, M. (2015). Toward a model of explaining teachers' innovative behavior a literature review. Review of Educational Research, 85(3), 430-471.

Tschannen-Moran, M., \& Johnson, D. (2011). Exploring literacy teachers' self-efficacy beliefs: Potential sources at play. Teaching and Teacher Education, 27(4), 751-761.

Tschannen-Moran, M., \& Woolfolk Hoy, A. (2007). The differential antecedents of self-efficacy beliefs of novice and experienced teachers. Teaching and Teacher Education, 23(6), 944-956.

Usher, E. L., \& Pajares, F. (2008). Sources of self-efficacy in school: Critical review of the literature and future directions. Review of Educational Research, 78(4), 751-796.

van der Want, A. C., den Brok, P., Beijaard, D., Brekelmans, M., Claessens, L. C. A., \& Pennings, H. J. M. (2019). The relation between teachers' interpersonal role identity and their self-efficacy, burnout and work engagement. Professional Development in Education, 45(3), 488-504.

Wang, J., \& Odell, S. J. (2007). An alternative conception of mentor-novice relationships: Learning to teach in reform-minded ways as a context. Teaching and Teacher Education, 23, 473-489.

Watson, C. (2006). Narratives of practice and the construction of identity in teaching. Teachers and Teaching: Theory and Practice, 12(5), 509-526.

Yin, R. (2018). Case study research and applications. Design and methods (6th ed.). SAGE Publications Inc.

Zee, M., \& Koomen, H. M. Y. (2016). Teacher self-efficacy and its effects on classroom processes, student academic adjustment, and teacher well-being: A synthesis of 40 years of research. Review of Educational Research, 86(4), 981-1015.

Publisher's Note Springer Nature remains neutral with regard to jurisdictional claims in published maps and institutional affiliations. 